\title{
Komposisi tangkapan tuna hand line di Pelabuhan Perikanan Samudera Bitung, Sulawesi Utara
}

\author{
Catch composition of tuna hand line fishery in Bitung Oceanic Fishing Port, North Sulawesi
}

FRANKY ADRIAN DARONDO*, LEFRAND MANOPPO dan ALFRET LUASUNAUNG

Program Studi Pemanfaatan Sumberdaya Perikanan, Fakultas Perikanan dan Ilmu Kelautan, Universitas Sam Ratulangi, Manado 95115

\begin{abstract}
Tuna is one of economically important fish species in the world and is the third largest fishery commodities in Indonesia after the shrimp and fish base. Tuna is relatively more expensive than other fish, and the demand tends to increase. The main problem to be observed is to know the of tuna landed in Bitung Oceanic Fishing Port (OFP). This study aims to: (1) determine the size composition of catches of tuna hand line; (2) analyze the relationship between the length and weight of the catch. This data are taken from fish landing reports of tuna hand line in the period of August to October 2014. Data was analyzed using a simple regression. The result is $\mathrm{Y}=1 \times 10^{-07} \mathrm{X}^{3.93}$ with a coefficient of determination $\mathrm{R}^{2}=0.91$. This high coefficient means that the model was good and valid. The value of $b$ in the equation was 3.93 and statistically it means that the growth pattern of yellow fin tuna landed in PPS Bitung was positive allometric $(b>3)$, i.e. the weight growth faster than the length.
\end{abstract}

Keywords: yellow fin tuna, length and weight, patterns of growth.

\begin{abstract}
ABSTRAK
Ikan tuna (Thunnus sp) adalah salah satu jenis ikan ekonomis penting di dunia dan merupakan komoditi perikanan terbesar ketiga di Indonesia setelah udang dan ikan dasar. Ikan tuna memiliki harga yang relatif lebih mahal dibandingkan harga komoditas ikan lainnya dengan permintaan terus meningkat. Pokok permasalahan yang ingin diteliti adalah mengetahui ukuran ikan tuna yang didaratkan di Pelabuhan Perikanan Samudera (PPS) Bitung. Penelitian ini bertujuan untuk: (1) mengetahui komposisi ukuran hasil tangkapan tuna hand line; (2) menganalisis hubungan panjang dan berat hasil tangkapan tuna hand line. Data panjang dan berat ikan diperoleh dari data sekunder hasil tangkapan tuna hand line selama Agustus sampai Oktober 2014. Data diolah dengan memakai regresi sederhana. Hasil analisis diperoleh $\mathrm{Y}=1 \times 10^{-07} \mathrm{X}^{3,93}$ dengan koefisien determinasi $\mathrm{R}^{2}=0,91$. Koefisien determinasi sebesar ini menunjukkan bahwa model yang diusulkan memenuhi syarat atau valid. Nilai b pada persamaan panjang berat tuna madidihang adalah 3,93 dan secara statistika dapat dikatakan pola pertumbuhan madidihang yang didaratkan di PPS Bitung adalah allometris positif $(b>3)$, yaitu pertambahan berat lebih cepat dari pada pertambahan panjang.
\end{abstract}

Kata-kata kunci: tuna madidihang, panjang dan berat, pola pertumbuhan

\section{PENDAHULUAN}

Tuna adalah salah satu jenis ikan ekonomis penting di dunia dan merupakan komoditi perikanan terbesar ketiga di Indonesia setelah udang dan ikan dasar. Ikan tuna memiliki harga yang relatif lebih mahal dibandingkan harga

\footnotetext{
${ }^{*}$ Penulis untuk penyuratan; email: frankydarondo82@gmail.com
}

komoditas ikan lainnya dengan permintaan yang terus meningkat (Anonimus, 2011).

Tuna (Thunnus sp) termasuk dalam keluarga Scombroidae, tubuhnya seperti cerutu mempunyai dua sirip punggung, sirip depan yang biasanya pendek dan terpisah dari sirip belakang. Mempunyai jari-jari sirip tambahan (finlet) di belakang sirip punggung dan dubur. Sirip dada terletak agak ke atas, sirip perut kecil, agak ke dalam dengan jari-jari penyokong menutup di 
seluruh ujung hipural. Tubuh ikan tuna tertutup oleh sisik-sisik kecil, berwarna biru tua dan agak gelap pada bagian atas tubuhnya, sebagian besar memiliki sirip tambahan yang berwarna kuning cerah dengan pinggiran berwarna gelap (Anonimus, 2011).

Tuna adalah ikan laut yang terdiri dari beberapa spesies dari famili Scombridae, terutama genus Thunnus. Tidak seperti kebanyakan ikan yang memiliki daging berwarna putih, daging ikan ini berwarna merah muda sampai merah tua. Hal ini karena otot tuna lebih banyak mengandung myoglobin dari pada ikan lainnya. Beberapa spesies tuna yang lebih besar, seperti tuna sirip biru (bluefin tuna), dapat menaikkan suhu darahnya di atas suhu air dengan aktivitas ototnya. Hal ini menyebabkan mereka dapat hidup di air yang lebih dingin dan dapat bertahan dalam kondisi yang beragam. Tuna adalah ikan yang memiliki nilai komersial tinggi (Anonimus, 2009). Menurut Uda (1952) dalam Laevastu dan Hela (1970) tuna mata besar (Thunnus obesus) menyebar dari Samudera Pasifik melalui perairan di antara pulau-pulau di Indonesia sampai di Samudera Hindia. Ikan ini terutama ditemukan di perairan sebelah selatan Jawa, sebelah barat daya Sumatera Selatan, Bali, Nusa Tenggara, Laut Banda dan Laut Maluku.

Tuna menyebar luas di seluruh perairan tropis dan subtropis. Penyebaran jenis-jenis tuna tidak dipengaruhi oleh perbedaan garis bujur (longitude) tetapi dipengaruhi oleh perbedaan garis lintang (latitude) (Nakamura,1969 dalam Muh. Ali Yahya et al., 2001). Albakora ditemukan di sekitar $10^{\circ}$ LU dan $30^{\circ}$ LS di Samudera Hindia, sedangkan tuna mata besar dan madidihang (Thunnus albacares) ditemukan pada lintang yang sama, hanya saja untuk tuna mata besar biasanya pada daerah yang suhunya lebih rendah (Colllette et al., 2001). Khususnya di Indonesia (Uktolseja et al., 1991), tuna didapatkan hampir menyebar di seluruh perairan Indonesia. Rasdani (2000) menyatakan secara umum daerah penangkapan ikan (fishing ground) didefinisikan sebagai salah suatu daerah atau wilayah perairan baik perairan tawar, laut maupun lautan (samudera) yang menjadi sasaran atau tujuan penangkapan, karena di daerah ini diharapkan dapat tertangkap ikan atau non-ikan dalam jumlah yang sebanyak-banyaknya.

Menurut Effendie (2002), faktor yang mempengaruhi pertumbuhan dapat digolongkan menjadi dua bagian yang besar yaitu faktor dalam dan luar. Faktor ini ada yang dapat dikontrol dan ada juga yang tidak. Faktor dalam pada umumnya faktor yang sukar dikontrol, di antaranya ialah keturunan, sex, umur, dan penyakit.

Pelabuhan Perikanan Samudera (PPS) Bitung merupakan salah satu pelabuhan yang strategis untuk mengembangkan perikanan tuna dengan alat penangkap tuna dengan kapal pancing ulur tuna (tuna hand lines). Hand line adalah alat penangkap tuna yang paling efektif dan dominan di Laut Maluku dengan menghasilkan kualitas hasil tangkapan tuna yang bagus dan harga yang tinggi.

Hand line tuna paling banyak digunakan nelayan di Bitung yang beroperasi di sekitar perairan Maluku, karena di perairan Maluku ini terdapat banyak rumpon sebagai tempat ikan tuna berkumpul.

Perkembangan armada perikanan tuna hand liner yang sangat cepat dewasa ini (468 unit) telah mengakibatkan tertangkapnya ikan tuna dalam jumlah yang cukup tinggi dengan variasi ukuran yang berbeda. Oleh kerena itu diperlukan pengetahuan tentang pertumbuhan ukuran tangkapan tuna tersebut. Pola pertumbuhan ikan dapat diketahui melalui hubungan panjang dan berat hasil tangkapan. Dengan mengetahui hubungan regresif tersebut, diharapkan dapat digunakan dalam pengelolaan komposisi tangkapan pancing ulur tuna, perikanan tuna tersebut secara berkelanjutan. Tujuan penelitian ini adalah: (1) Mengetahui komposisi ukuran hasil tangkapan tuna hand line; (2) Menganalisis hubungan panjang dan berat hasil tangkapan tuna hand line. Penelitian ini dilaksanakan di PPS Bitung selama Agustus 2014 sampai Oktober 2014.

\section{METODE PENELITIAN}

\section{Metode pengumpulan data}

Penelitian ini dilakukan dengan mengikuti metode deskriptif (Nazir, 1998) dalam Prastowo, 2001). Teknik pengumpulan data dalam penelitian dilakukan dengan cara pengamatan langsung di lokasi penelitian, dan melakukan pengukuran serta wawancara (mengisi kuisioner) dengan ABK kapal pancing ulur tuna yang mendaratkan hasil tangkapannya di PPS Bitung. Metode pengambilan sampel dilakukan setelah ikan didaratkan, dengan jumlah sampel 20 ekor dari 18.000 ekor ikan per bulan, dan rata-rata berat $38,15 \mathrm{~kg}$. Kemudian dilakukan pengukuran morfometrik dengan menggunakan meteran lalu ditimbang dengan 
menggunakan timbangan digital. Data tersebut diseleksi dari ukuran terendah sampai tertinggi baik panjang maupun berat.

\section{Metode analisis data}

Data yang diperoleh diolah dalam bentuk tabel dan digambarkan dalam bentuk grafik. Analisis statistik yang digunakan adalah analisis regresi sederhana antara dua peubah (variables) yaitu panjang dan berat ikan. Hubungan panjang dengan berat hampir mengikuti hukum kubik yaitu bahwa berat ikan sebagai pangkat tiga dari panjangnya, dengan rumus

$$
\mathrm{W}=\mathrm{cL}^{\mathrm{n}}
$$

yang kemudian ditransformasikan ke dalam persamaan logaritma menjadi

$$
\log \mathrm{W}=\log \mathrm{c}+\mathrm{n} \log \mathrm{L},
$$

di mana $\mathrm{W}$ adalah berat ikan, $\mathrm{L}$ panjang ikan, $\mathrm{c}$ dan L konstanta atau secara sederhana dituliskan sebagai $\mathrm{Y}=\mathrm{a}+\mathrm{bX}$, di mana $\mathrm{Y}=\log \mathrm{W}, \mathrm{X}=\log$ $\mathrm{L}, \mathrm{a}=\log \mathrm{c}$ (intersep), dan $\mathrm{b}$ slope (konstanta).
Setelah data panjang dan berat ditransformasi ke dalam bentuk logaritma, selanjutnya untuk mendapatkan koefisien regresi data diolah dengan metode grafis yang disediakan dalam perangkat lunak MS Excel. Selanjutnya diinterpretasikan untuk menarik kesimpulan.

\section{HASIL DAN PEMBAHASAN}

\section{Komposisi ukuran hasil tangkapan}

Hasil tangkapan kapal tuna hand line yang didaratkan di PPS Bitung terdiri dari dua spesies yaitu: ikan tuna sirip kuning atau madidihang dan ikan tuna matabesar. Produksi hasil tangkapan ikan tuna hand line yang didaratkan di PPS Bitung dari bulan Agustus sampai Oktober 2014 berjumlah 1080,88 $\mathrm{kg}$ yang didominasi oleh ikan madidihang yaitusekitar $94 \%$ dari total tuna yang ditangkap, kemudian diikuti tuna mata besar $6 \%$. Komposisi ukuran panjang dan berat ikan madidihang yang tertangkap dari Agustus sampai Oktober dapat dilihat pada Tabel 1.

Tabel 1. Komposisi ukuran panjang dan berat ikan madidihang yang tertangkap pada bulan Agustus, September dan Oktober 2014

\begin{tabular}{lcccccc}
\hline & No & \multicolumn{2}{c}{ Agustus 2014 } & \multicolumn{2}{c}{ September 2014 } & \multicolumn{2}{c}{ Oktober 2014 } \\
\cline { 2 - 6 } & $\begin{array}{c}\text { Panjang Cagak } \\
(\mathrm{cm})\end{array}$ & Berat (kg) & $\begin{array}{c}\text { Panjang Cagak } \\
(\mathrm{cm})\end{array}$ & Berat (kg) & $\begin{array}{c}\text { Panjang Cagak } \\
(\mathrm{cm})\end{array}$ & Berat (kg) \\
\hline 1. & 132 & 30 & 142 & 40 & 145 & 42 \\
2. & 125 & 20 & 153 & 50 & 136 & 34 \\
3. & 140 & 38 & 125 & 20 & 135 & 32 \\
4. & 134 & 30 & 134 & 30 & 134 & 30 \\
5. & 139 & 36 & 145 & 40 & 161 & 58 \\
6. & 136 & 38 & 136 & 38 & 154 & 50 \\
7. & 143 & 40 & 143 & 40 & 140 & 38 \\
8. & 155 & 48 & 155 & 48 & 152 & 50 \\
9. & 150 & 48 & 125 & 20 & 151 & 48 \\
10. & 144 & 41 & 134 & 30 & 155 & 50 \\
11. & 145 & 42 & 124 & 20 & 145 & 43 \\
12. & 146 & 42 & 130 & 26 & 145 & 41 \\
13. & 135 & 34 & 132 & 28 & 150 & 52 \\
14. & 135 & 32 & 150 & 48 & 134 & 41 \\
15. & 130 & 26 & 136 & 30 & 145 & 40 \\
16. & 132 & 28 & 162 & 58 & 136 & 38 \\
17. & 124 & 20 & 142 & 41 & 140 & 42 \\
18. & 142 & 40 & 147 & 45 & 128 & 26 \\
19. & 153 & 50 & 150 & 45 & 135 & 30 \\
20. & 150 & 51 & 142 & 40 & 140 & 35 \\
\hline Jumlahy & 2.790 & 734 & 2.807 & 737 & 2.861 & 818 \\
\hline Rata-rata & 139,5 & 36,7 & 140,35 & 36,85 & 143,05 & 40,9 \\
\hline
\end{tabular}


Dari Tabel 1 dapat dilihat komposisi ukuran panjang cagak (fork length) dan berat ikan madidihang yang tertangkap selama Agustus 2014 paling banyak tertangkap pada ukuran panjang 124-155 cm dan berat $20-51 \mathrm{~kg}$; sementara pada September 2014 dengan ukuran 124-162 cm dan berat $20-58 \mathrm{~kg}$ dan pada Oktober 2014, 128-161 $\mathrm{cm}$ dan berat $26-58 \mathrm{~kg}$.

\section{Hubungan panjang dan berat}

Dari hasil analisis hubungan panjang dan berat selama 3 bulan penelitian (Agustus-Oktober 2014) untuk sampel tuna madidihang sebagaimana dicantumkan pada Tabel 1, menghasilkan jumlah hasil tangkapan tuna dari Agustus sampai Oktober 2014 terbesar adalah madidihang yaitu 94\% dari total tuna yang ditangkap, kemudian diikuti tuna mata besar $(6 \%)$, sebagaimana tercantum pada data Tabel 2 dan Gbr. 1.

Tabel 2. Produksi hasil tangkapan tuna hand line yang didaratkan di PPS Bitung Tahun 2014

\begin{tabular}{llc}
\hline No & Waktu (2014) & Jumlah Produksi $(\mathrm{kg})$ \\
\hline 1 & Januari & 164,021 \\
2 & Februari & 134,980 \\
3 & Maret & 234,467 \\
4 & April & 365,476 \\
5 & Mei & 357,401 \\
6 & Juni & 404,469 \\
7 & Juli & 304,960 \\
8 & Agustus & 269,911 \\
9 & September & 371,814 \\
10 & Oktober & 439,153 \\
\hline
\end{tabular}

(Sumber PPS Bitung)

Untuk ikan madidihang paling banyak tertangkap pada 3 bulan terakhir pada frekuensi di kisaran panjang antara $125-172 \mathrm{~cm}$ dan berat antara $20-68 \mathrm{~kg}$. Gbr. 2 memperlihatkan hubungan panjang ikan tuna madidihang yang tertangkap selama Agustus-Oktober 2014.

Berdasarkan hasil analisis diperoleh bahwa hubungan panjang dan berat ikan tuna madidihang yang tertangkap selama Agustus sampai Oktober 2014 memiliki persamaan matematis $\mathrm{Y}=1 \mathrm{E}^{-}$ ${ }^{07} \mathrm{X}^{3,926}$ dengan koefisien determinasi $\mathrm{R}^{2}=0,909$, ini berarti bahwa hubungan panjang dan berat ikan sangat signifikan; karena dengan tingkat koefisien determinasi sebesar ini maka model yang diusulkan memenuhi syarat atau valid.

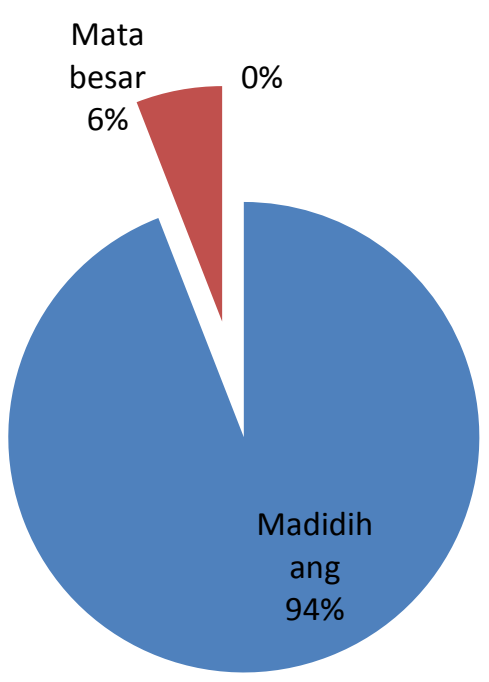

Gambar 1. Diagram komposisi ikan tuna bulan JanuariOktober 2014.

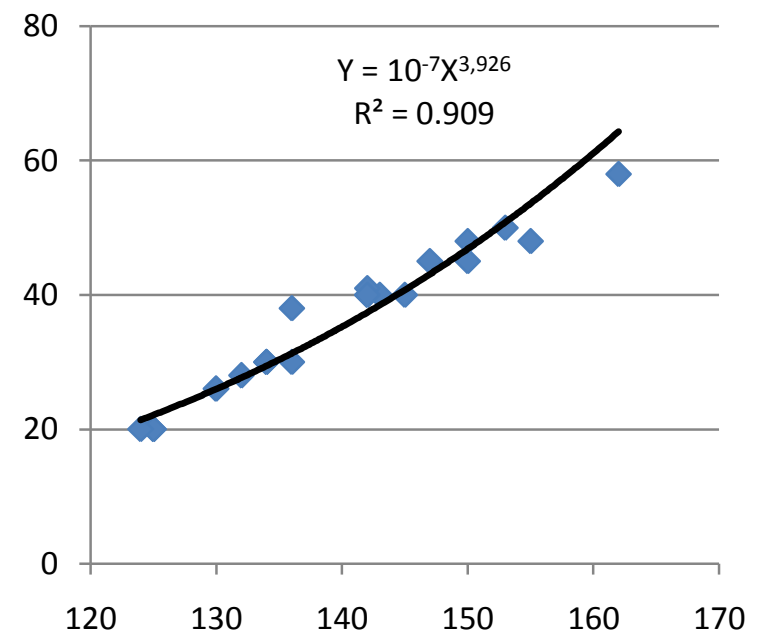

Gambar 2. Hubungan panjang dan berat ikan madidihang yang tertangkap selama Agustus-Oktober 2014.

Adapun kriteria pola pertumbuhan ikan dengan menggunakan panjang berat tergantung pada nilai koefisien regresinya atau nilai $\mathrm{b}$ tersebut, harga nilai eksponen tersebut untuk semua jenis ikan sudah diketahui berkisar 1,2-4,0 namun kebanyakan harga $b$ berkisar antara 2,4-3,5. Ada 3 kemungkinan nilai $b$ yang diperoleh, yaitu:

- Apabila nilai koefisien regresi < 3, maka pertambahan panjang lebih cepat dari pada pertambahan berat atau disebut alometrik negatif. 
- Apabila nilai koefisien regresi > 3, maka pertambahan berat lebih cepat daripada pertambahan panjang atau disebut alometrik positif.

- Apabila nilai koefisien regresi $=3$, maka pertambahan panjang dan pertambahan beratnya seimbang atau isometrik.
Setelah data panjang dan berat ditransformasikan ke dalam bentuk logaritma dan diolah dengan metode grafis yang mendapatkan formula hubungan antara panjang dan berat madidihang, langkah selanjutya adalah mengetahui nilai koefisien regresinya atau nilai $b$ tersebut, dengan perhitungan Anova yang disajikan dalam Tabel 3.

Tabel 3. Hasil summary output analisis regresi

\begin{tabular}{lr}
\hline \multicolumn{2}{c}{ Regression Statistics } \\
\hline Multiple R & 0.953424382 \\
R Square & 0.909018053 \\
Adjusted R Square & 0.907421878 \\
Standard Error & 0.036404034 \\
Observations & 59 \\
\hline
\end{tabular}

\begin{tabular}{|c|c|c|c|c|c|c|}
\hline & $d f$ & & SS & MS & $F$ & Significance $F$ \\
\hline Regression & & 1 & 0.754729193 & 0.75473 & 569.49791 & $2.35669 \mathrm{E}-31$ \\
\hline Residual & & 57 & 0.075539458 & 0.00133 & & \\
\hline Total & & 58 & 0.830268651 & & & \\
\hline
\end{tabular}

\begin{tabular}{|c|c|c|c|c|c|c|c|}
\hline & Coefficients & Standard Error & tStat & P-value & Lower 95\% & Upper 95\% & Lower $95.0 \%$ Upper $95.0 \%$ \\
\hline Intercept & -6.891003855 & 0.354493961 & -19.439 & 7.954E-27 & -7.600865761 & -6.18114195 & $-7.6008658-6.18114195$ \\
\hline X Variable 1 & 3.936891006 & 0.164970892 & 23.8642 & $2.357 \mathrm{E}-31$ & 3.606542496 & 4.267239517 & $3.6065425 \quad 4.26723952$ \\
\hline
\end{tabular}

Tabel 3 mengambarkan tentang hasil perhitungan Anova melalui transformasi logaritma natural yang mendapatkan variabel $\mathrm{X}=3.9368$ yang berarti nilai $b$ pada persamaan panjang berat bulanan tuna madidihang adalah 3,93 dan secara statistik dapat dikatakan pola pertumbuhan ikan tuna madidihang yang didaratkan di PPS Bitung terkategori allometris positif (b>3), yaitu pertumbuhan panjang tidak secepat pertumbuhan beratnya.

\section{KESIMPULAN}

Berdasarkan hasil penelitian ini maka dapat disimpulkan: (1) Komposisi ukuran hasil tangkapan tuna yang tertangkap dari Agustus sampai Oktober didominasi oleh ikan tuna madidihang yaitu $94 \%$ dari total tuna yang ditangkap, sementara tuna mata besar hanya $6 \%$. Panjang ikan tuna yang tertangkap selama penelitian ini berkisar $50-172 \mathrm{~cm}$ dan berat 3,5-68 kg. Hasil tangkapan ikan tuna madidihang memiliki frekuensi terbanyak dengan ukuran panjang 125-172 $\mathrm{cm}$ dan berat 20-68 kg; (2) Analisis hubungan panjang dan berat menunjukkan bahwa pertumbuhan tuna madidihang yang di daratkan di PPS Bitung, selama pengamatan mengikuti pola pertumbuhan allometrik positif ( $\mathrm{b}$ $>3$ ), dengan kata lain pertambahan berat lebih cepat dari pada pertambahan panjang.

\section{DAFTAR PUSTAKA}

Anonimous, 2009. Jenis-jenis ikan laut. http://opiegdwib. blogspot.com/2009, diakses tanggal 20 Desember 2014.

Anonimous, 2011. Klasifikasi ikan tuna. http://kuliahitukeren. blogspot.com/2011, diakses tanggal 20 Desember 2014.

Anonimous, 2011. Panduan penangkapan dan penanganan perikanan tuna.WWF, Jakarta.

Collette, B.B. 2001. Systematics of the tunas and mackerels. Tuna Research and Conservation Center, United States.

Effendie, M.I. 2002. Biologi Perikanan. Yayasan Pustaka Nusantara, Yogyakarta. 
F.A. Darondo dkk.

Hela, I. dan T. Laevastu. 1970. Fisheries Oceanography. Fishing News (Books) LTD., London.

Muh. Ali yahya, at al. 2001. Pemanfaatan sumber daya tuna dan cakalang secara terpadu. IPB, Bogor.

Prastowo, A. 2011. Metode Penelitian Kualitatif dalam Perspektif Rancangan Penelitian. Ar-Ruzz Media, Jogjakarta.
Rasdani M. 2000. Daerah penangkapan ikan tuna dan cakalang di dunia. BPPI, Semarang

Uktolseja, J.C.B. 1987. Jurnal Penelitian Perikanan laut. Jakarta 